удк 339.138

DOI: https://doi.org/10.32851/2708-0366/2021.9.8

\author{
Фірсова С.Г. \\ кандидат економічних наук, \\ доцент кафедри менеджменту інноваційної \\ та інвестиційної діяльності, \\ Київський національний університет \\ імені Тараса Шевченка \\ Деметер Д.є. \\ студентка, \\ Київський національний університет \\ імені Тараса Шевченка
}

Firsova Svetlana, Demeter Diana

Taras Shavchenko National University of Kyiv

\title{
МЕТОДИЧНІ ПІДХОДИ ДО ОЦІНЮВАННЯ РІВНІВ РИНКОВИХ ПОЗИЦІЙ НОВОГО БРЕНДУ
}

\section{METHODICAL BASES TO MARKET POSITIONS EVALUATION OF A NEW BRAND}

Бренди нині є рушійною силою успішності підприємств через зростаючий рівень конкурениії та розширення асортименту на ринку пропозиції. Сильний бренд - цее ключова конкурентна перевага, щуо стимулює споживача придбати товар. Зважаючи на важливість бренду, зауважуємо, щзо методики оцінювання позицій бренду на ринку нині потребують удосконалення з точки зору визначення критерїв оиінки. Стаття містить аналіз підходів до оиінювання ринкових позицій бренду, перелік факторів, що можуть на нього впливати. Розроблено авторську модель очінювання ринкових позицій бренду з переліком факторів впливу на бренд та їх важливості. Запропоновано графічне зображення результатів дослідження для визначення основних можливостей та позицій серед конкурентів. Стаття дає змогу практично застосовувати авторський метод для оцінювання бренду в умовах конкурениії.

Ключові слова: бренд, сила бренду, оијнка бренду, маркетинговий аналіз, фактори впливу на бренд, комплексна оцінка.

Бренды сегодня являются движущей силой успешности предприятий из-за растущего уровня конкуренции и расширения ассортимента на рынке предложения. Сильный бренд - это ключевое конкурентное преимущество, которое стимулирует потребителя приобрести товар. Учитывая важность бренда, замечаем, что методики оиенивания позииий бренда на рынке сейчас нуждаются в совершенствовании с точки зрения определения критериев оценки. Статья содержит анализ подходов к оцениванию рыночных позищий бренда, перечень факторов, которые могут на него влиять. Разработана авторская модель оценивания рыночных позищий бренда с перечнем факторов влияния на бренд и их важности. Предложено графическое изображение результатов исследования для определения основных возможностей и позищий среди конкурентов. Статья позволяет практически применять авторский метод для оченивания бренда в условиях конкуренции.

Ключевые слова: бренд, сила бренда, оченка бренда, маркетинговый анализ, факторы влияния на бренд, комплексная оченка.

Our world is dynamic and competitive. Today, brands are the driving force behind the success of enterprises due to the growing level of competition and expanding the range in the supply market. This is one of the reasons why modern companies rely on the development and support of their brands, strengthening their position in the market. A strong brand is one of the main competitive company's advantages and it encourages the consumer to buy the product and be a 
constant loyal consumer of the brand. It is important to keep in mind that the number of loyal customers is not the only and main factor in the brand's success in the market. Brand is a broad multifactorial concept that requires deep analysis of all components. Given the importance of the brand, we note that the methods of assessing the position of the brand in the market still need to be improved in terms of defining evaluation criteria. Most often, models of brand strength assessment consider one of the directions of its strength, while brand needs to be considered comprehensively, including both financial and market indicators, and the attitude of consumers to the brand. This article contains an analysis of approaches to assessing the market position of the brand by global scientists, identifies a list of factors that may affect the brand. In the process of writing the article, an author's comprehensive model for assessing the market position of the brand was developed with a list of factors influencing the brand and their importance based on the assessment of factors by practitioners. A graphical representation of the research results is proposed to determine the main opportunities and positions among competitors. This article allows you to practically apply the author's method to assess the brand in a competitive environment and comprehensively assess the brand's position in the market. The article will help not only to learn the factors of brand evaluation by different scientists, but also can encourage readers to think and develop their own methods of brand evaluation because the modern market is very dynamic and requires constant improvement.

Key words: brand, brand strength, brand evaluation, marketing analysis, factors influencing the brand, comprehensive evaluation.

Постановка проблеми. В умовах всесвітньої пандемії коронавірусної хвороби темпи економічного зростання мають циклічний характер, а саме з тенденцією до зменшення у періоди локдаунів. Це зумовлює підвищення конкуренції та боротьби за ринкові позиції як серед провідних гравців ринку, так і серед новачків. Рівень конкуренції на ринку зростає, отже, загострюється питання визначення конкурентоспроможності товарної пропозиції під відомими та новими брендами, сили бренду, іміджу в очах споживачів. Особливо гострим це питання є для нових брендів, тому що після запуску, куди зазвичай вкладають дуже багато ресурсу, важливим етапом $\epsilon$ оцінювання сили бренду на ринку та його подальших перспектив розвитку, таких як рівень впізнавання, зростання вартості, домінація в продуктовій категорії, відповідність потребам споживачів. 3 огляду на те, що методичний інструментарій оцінювання ринкових позицій бренду (в тому числі, нового) потребує вдосконалення та подальших наукових досліджень, актуальність тематики статті можна вважати об’єктивною.

Аналіз останніх досліджень і публікацій. В сучасній та класичній літературі теоретичні надбання про створення, позиціонування та оцінювання бренду свого часу розробляли провідні світові та вітчизняні економісти, зокрема Д. Аакер, Ф. Котлер, М. Портер, Дж. Еванс, Ж.-Ж. Ламбен, А. Длігач, О. Власенко, А. Старостіна.

Актуальність проблеми управління та забезпечення виведення нового бренду на ринок підтверджує відсутність єдиного алгоритму до практичної реалізації важливого етапу запуску нового бренду, а саме оцінювання результатів запуску бренду.

Теоретичні дослідження наявних методик оцінювання ринкових позицій бренду потребують удосконалення щодо систематизації критеріїв оцінки ринкових позицій нового бренду на ринку.

Формулювання цілей статті. Метою статті є обгрунтування та структурування критеріїв оцінювання ринкових позицій нового бренду для об'єктивізації рівнів його ринкових позицій.

Завданнями статті є визначення основних характеристик бренду, що комплексно його характеризують; оцінювання характеристик та розрахунок позицій бренду.

Виклад основного матеріалу. Бренд $є$ важливим фактором успіху товару. Так, сильний бренд свідчить про високі позиції товару на ринку. Наукова література налічує багато підходів до трактування терміна «бренд». Т. Амблер [4, с. 32-35] робив акцент на тому, що покупець надає додаткову цінність продукту через його індивідуа- 
лізацію. Д. Аакер визначав бренд як символ, що може посилювати або послаблювати товар чи послугу [3, с. 98]. Оскільки бренд і його позиції на ринку є ключовою темою дослідження, пропонуємо розглянути, які нині існують методи оцінювання бренду. Нижче нами запропоновано перелік уже наявних методик закордонних дослідників як основу для подальших теоретичних розробок.

Модель М. Шерінгтона. М. Шерінгтон пропонував оцінювати ефективність брендингу з використанням ключових індикаторів ефективності (KIE), що пов'язані зі стратегією компанії та ії баченням ринку. Автор пропонував визначити один домінантний KIЕ та фокусуватися на ньому, перевіряючи, чи досягається ціль [5, с. 220-224]. Проте, на нашу думку, зведення такого широкого комплексного конструктиву, як бренд, до єдиного показника не $є$ коректним та правильним, адже нівелює врахування всіх аспектів та факторів впливу на його розвиток.

Модель Д. Аакера. Один із провідних світових науковців бренд-менеджменту вважав, що ефективність бренду необхідно оцінювати на основі аналізу показників використання активів капіталу, таких як обізнаність про бренд, сприйняття якості бренду, його лояльність та емоції, що він викликає. Автор створив власну систему оцінювання використання активів, яка має назву «Десятка показників капіталу бренду» (“Brand Equity Ten”). При цьому автор відзначає, що ефективне управління брендом включає не лише фінансові показники, але й поведінкові та ринкові. В табл. 1 перераховані показники, зазначені автором [3, с. 375-378].

Таблиця 1

Десятка показників капіталу бренду

\begin{tabular}{|c|c|c|c|}
\hline Тип оцінки & Група & Показники & Коментар \\
\hline \multirow{4}{*}{ Споживча } & Прихильність & $\begin{array}{l}\text { 1) Цінова премія; } \\
\text { 2) лояльність } \\
\text { бренду. }\end{array}$ & \multirow{4}{*}{$\begin{array}{l}\text { Споживацькі оцінки активів } \\
\text { марочного капіталу, } \\
\text { що отримуються } \\
\text { в результаті досліджень }\end{array}$} \\
\hline & Сприйняття & $\begin{array}{l}\text { 3) кідерство; } \\
\text { 4) популярність. }\end{array}$ & \\
\hline & Асоціації & $\begin{array}{l}\text { 5) цінність; } \\
\text { 6) індивідуальність } \\
\text { бренду; } \\
\text { 7) асоціація } \\
\text { з організацією. }\end{array}$ & \\
\hline & Обізнаність & $\begin{array}{l}\text { 8) обізнаність } \\
\text { про бренд. }\end{array}$ & \\
\hline Ринкова & & $\begin{array}{l}\text { 9) доля ринку; } \\
\text { 10) дистрибуція. }\end{array}$ & $\begin{array}{l}\text { Відображення фактичної } \\
\text { ситуації на ринку }\end{array}$ \\
\hline
\end{tabular}

Джерело: [3, с. 375-378]

На думку автора, основним параметром є лояльність покупця до бренду, тому що вона є вхідним бар'єром для конкурента та перешкодою за деструктивної цінової конкуренції.

Підхід Т. Муноза та С. Кумара. Автори пропонують будувати оцінку бренду на основі трьох груп метрик, таких як сприйняття, поведінкові та фінансові метрики. Кожна компанія повинна сама визначати те, які саме показники будуть входити до кожної групи, залежно від власних пріоритетів [2, с. 381-387]. Недоліком цієї моделі $\epsilon$ те, що вона не включає ринкові показники. До них можуть належати частка ринку, дистрибуція, ціновий індекс, офтейк (продажі бренду з однієї точки дистрибуції) тощо. 
Дослідження Д. Лемана, К. Келлера, Дж. Фарлея. Автори працювали над визначенням універсальних бренд-метрик, які були б очищеними від крос-культурних відмінностей у сприйнятті бренду. Дослідження дало змогу сформувати шість ключових груп метрик бренду, таких як розуміння бренду, порівняльні переваги, міжособистісні відносини, історія бренду, перевага бренду, прихильність. На жаль, ці параметри стосуються виключно споживчих метрик, проте їх можна застосовувати як частину загальної моделі [1, с. 29-56].

Ознайомившись із підходами відомих дослідників до визначення критеріїв для оцінювання бренду та оцінивши їх переваги й недоліки, пропонуємо авторську комплексну 12-факторну модель оцінювання позицій бренду.

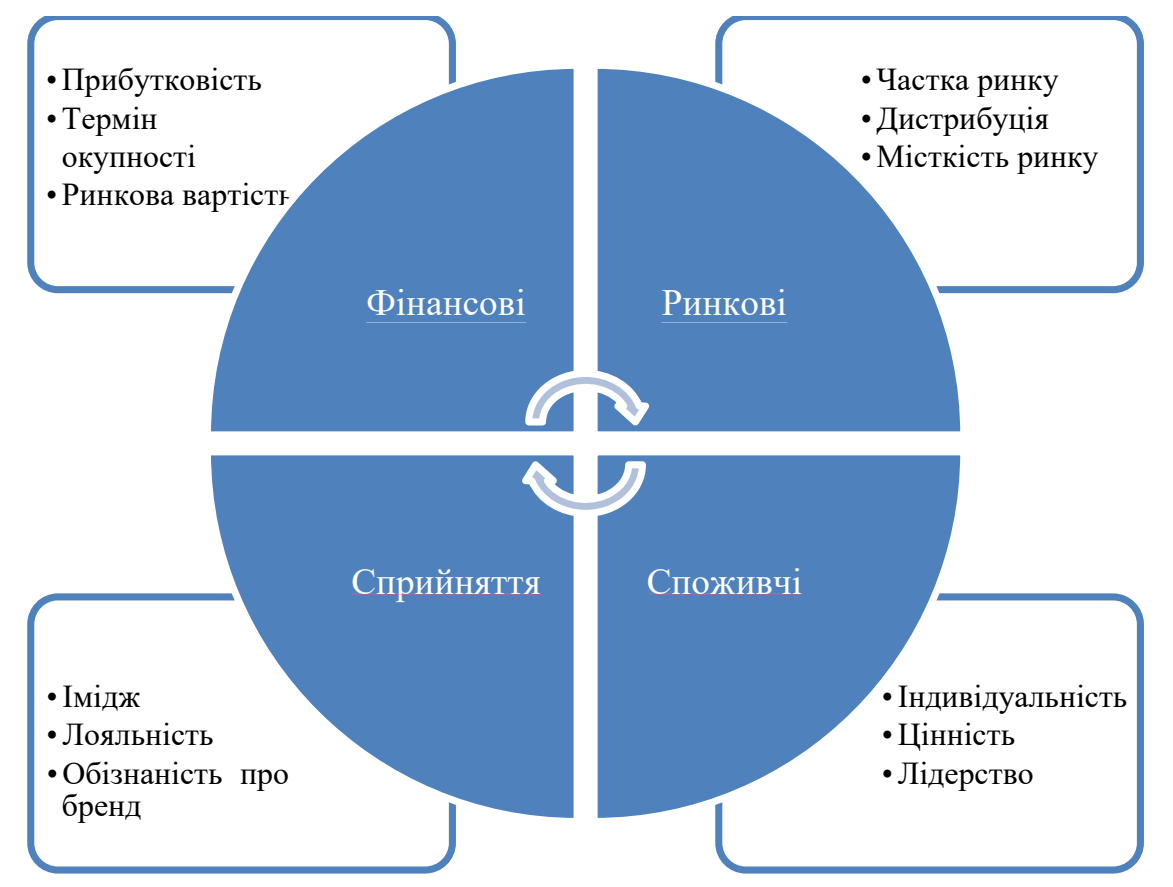

Рис. 1. Критерії оцінювання сили бренду

Джерело: авторська розробка

Ця модель, на нашу думку, актуалізується під час виведення на ринок нового бренду та необхідності постійного моніторингу його ринкових позицій.

У табл. 2 надано більш детальну характеристику кожного параметру вибраних критеріїв.

Як видно 3 табл. 2, кожен із параметрів має різні шкали виміру, отже, метрики потребують зведення до єдиного нормованого значення. Пропонуємо кожен із параметрів оцінювати в балах.

Для оцінювання визначення вагомості кожної групи було опитано працівників двох вітчизняних компаній (позначимо їх «А» та «Б»), що мають сильні бренди на ринку. Експертам було запропоновано проранжувати групи критеріїв від 1 до 4, де 4 - найвище значення. Таблиця результатів має такий вигляд.

Після визначення вагомості кожної групи необхідно визначити вагомість кожного параметру у відповідній критеріальній групі. Аналогічно до груп визначаємо вагомість параметрів методом експертних оцінок за ранжуванням від 1 до 3. 
Таблиця 2

Опис параметрів для 12-факторної моделі оцінювання бренду

\begin{tabular}{|c|l|l|}
\hline Критерій & \multicolumn{1}{|c|}{ Параметр } & \multicolumn{1}{c|}{ Опис } \\
\hline \multirow{5}{*}{ Фінансова } & Рентабельність & $\begin{array}{l}\text { Показник, що показує співвідношення прибутку та витрат } \\
\text { (\%). Чим більше 1, тим краще. }\end{array}$ \\
\cline { 2 - 3 } & $\begin{array}{l}\text { Термін } \\
\text { окупності }\end{array}$ & Час, необхідний на покриття витрат (роки). \\
\cline { 2 - 3 } & Ринкова вартість & Значення, що показує цінність бренду (грн). \\
\hline \multirow{5}{*}{ Ринкова } & Частка ринку & $\begin{array}{l}\text { Частка продукції бренду у загальному обсягу галузі, } \\
\text { в якій він діє (\%). }\end{array}$ \\
\cline { 2 - 4 } & Дистрибуція & Відсоток покриття ринку (\%). \\
\cline { 2 - 3 } & Місткість ринку & Наявний обсяг продажу товару (грн). \\
\hline \multirow{5}{*}{ Споживча } & Індивідуальність & Відмінна характеристика бренду від інших (бали). \\
\cline { 2 - 3 } & Цінність & Характер та позиція на ринку серед споживачів (бали). \\
\cline { 2 - 3 } & Лідерство & Наявність першості на ринку серед споживачів (бали). \\
\hline \multirow{5}{*}{ Сприйяття } & Імідж & Уявлення покупців про бренд (бали). \\
\cline { 2 - 3 } & Лояльність & Ступінь підтримки споживачами бренду (\%). \\
\cline { 2 - 3 } & Обізнаність & $\begin{array}{l}\text { Здатність споживача визначати і впізнавати продукт серед } \\
\text { різноманіття інших торгових марок за характерними } \\
\text { атрибутами бренду (\%). }\end{array}$ \\
\hline
\end{tabular}

Джерело: авторська розробка

Таблиця 3

Визначення вагомості груп критеріїв

\begin{tabular}{|l|c|c|c|c|c|c|c|c|c|c|c|}
\hline \multirow{2}{*}{ Критерій } & \multicolumn{7}{|c|}{ Експерт } & \multirow{2}{*}{ Сума } & \multirow{2}{*}{ Вага } \\
\cline { 2 - 13 } & $\mathbf{1}$ & $\mathbf{2}$ & $\mathbf{3}$ & $\mathbf{4}$ & $\mathbf{5}$ & $\mathbf{6}$ & $\mathbf{7}$ & $\mathbf{8}$ & $\mathbf{9}$ & & \\
\hline Фінансова & 1 & 3 & 2 & 1 & 4 & 3 & 4 & 1 & 1 & 20 & $22 \%$ \\
\hline Ринкова & 4 & 2 & 4 & 2 & 3 & 2 & 1 & 3 & 4 & 25 & $28 \%$ \\
\hline Споживча & 2 & 4 & 1 & 4 & 2 & 4 & 2 & 2 & 3 & 24 & $27 \%$ \\
\hline Сприйняття & 3 & 1 & 3 & 3 & 1 & 1 & 3 & 4 & 2 & 21 & $23 \%$ \\
\hline Загалом & & & & & & & & & & 90 & $100 \%$ \\
\hline
\end{tabular}

Джерело: авторська розробка

Після визначення ваги кожної групи та критерія можна оцінювати позиції бренду.

Інтегрована формула для оцінювання матиме такий вигляд:

$$
\mathrm{P} \text { brand }=\sum_{i=1}^{12} w_{i} * O_{i} * \overrightarrow{w_{j}} 10 *
$$

де P brand - інтегральна оцінка ринкових позицій бренду (сила бренду); $w_{i}$ - вага i-го параметру; $O_{i}$ - оцінка $i$-го параметру бренду; $w_{j}$ - вага $j$-ї групи; $10^{*}$ - максимально можливий бал, що може визначатися на розсуд постановника задачі.

Пропонуємо оцінити за цією методикою бренди компаній «А» та «Б».

Експертам було запропоновано оцінити їх бренд за кожним параметром від 1 до 10 балів, де 10 - найвищий. Результати наведено в табл. 5.

Чим вище показник інтегральної оцінки ринкових позицій бренду, тим вище сила бренду. Одержавши результати розрахунків інтегрального показника $\mathrm{P}_{\text {brand, }}$, доходимо висновку про рівень конкурентоспроможності ринкових позицій бренду. Для цього можна орієнтуватись на шкалу, наведену у таблиці. 
Таблиця 4

Визначення вагомості параметрів кожного критерія

\begin{tabular}{|c|c|c|c|c|c|c|c|c|c|c|c|}
\hline \multirow{2}{*}{ Показник } & \multicolumn{9}{|c|}{ Експерт } & \multirow{2}{*}{ Сума } & \multirow{2}{*}{ Вага } \\
\hline & 1 & 2 & 3 & 4 & 5 & 6 & 7 & 8 & 9 & & \\
\hline \multicolumn{12}{|c|}{ Фінансова } \\
\hline Рентабельність & 2 & 3 & 3 & 1 & 1 & 2 & 1 & 3 & 1 & 17 & $31 \%$ \\
\hline Термін окупності & 1 & 1 & 2 & 2 & 2 & 1 & 3 & 1 & 2 & 15 & $28 \%$ \\
\hline Ринкова вартість & 3 & 2 & 1 & 3 & 3 & 3 & 2 & 2 & 3 & 22 & $41 \%$ \\
\hline \multicolumn{12}{|c|}{ Ринкова } \\
\hline Частка ринку & 1 & 3 & 1 & 3 & 2 & 3 & 3 & 3 & 1 & 20 & $38 \%$ \\
\hline Дистрибуція & 3 & 2 & 3 & 1 & 1 & 1 & 2 & 2 & 2 & 17 & $31 \%$ \\
\hline Місткість ринку & 2 & 1 & 2 & 2 & 3 & 2 & 1 & 1 & 3 & 17 & $31 \%$ \\
\hline \multicolumn{12}{|l|}{ Споживча } \\
\hline Індивідуальність & 1 & 3 & 3 & 3 & 1 & 3 & 3 & 1 & 1 & 19 & $35 \%$ \\
\hline Цінність & 3 & 1 & 2 & 2 & 2 & 1 & 1 & 2 & 2 & 16 & $30 \%$ \\
\hline Лідерство & 2 & 2 & 1 & 1 & 3 & 2 & 2 & 3 & 3 & 19 & $35 \%$ \\
\hline \multicolumn{12}{|c|}{ Сприйняття } \\
\hline Імідж & 2 & 3 & 3 & 3 & 1 & 3 & 3 & 1 & 3 & 22 & $40 \%$ \\
\hline Лояльність & 1 & 2 & 2 & 2 & 2 & 1 & 1 & 3 & 2 & 16 & $30 \%$ \\
\hline Обізнаність & 3 & 1 & 1 & 1 & 3 & 2 & 2 & 2 & 1 & 16 & $30 \%$ \\
\hline
\end{tabular}

Джерело: авторська розробка

Таблиця 5

Оцінка брендів компанії за 12-факторною моделлю

\begin{tabular}{|c|c|c|c|c|c|c|c|}
\hline \multirow{2}{*}{ Критерії } & \multirow{2}{*}{ Параметри } & \multirow{2}{*}{$\begin{array}{c}\text { Вага } \\
\text { параметру }\end{array}$} & \multirow{2}{*}{$\begin{array}{c}\text { Вага } \\
\text { групи }\end{array}$} & \multicolumn{2}{|c|}{ Середній бал } & \multicolumn{2}{|c|}{$\mathbf{P}_{\text {brand }}$} \\
\hline & & & & «A» & «Б» & «A» & «Б» \\
\hline \multirow{3}{*}{ Фінансова } & Рентабельність & $31 \%$ & \multirow{3}{*}{$22 \%$} & 8,4 & 8,1 & 0,59 & 0,57 \\
\hline & Термін окупності & $28 \%$ & & 7,3 & 8,2 & 0,45 & 0,51 \\
\hline & Ринкова вартість & $41 \%$ & & 9,1 & 7,5 & 0,82 & 0,68 \\
\hline \multirow{3}{*}{ Ринкова } & Частка ринку & $37 \%$ & \multirow{3}{*}{$28 \%$} & 9,2 & 8,5 & 0,95 & 0,87 \\
\hline & Дистрибуція & $31 \%$ & & 8,9 & 7,5 & 0,78 & 0,66 \\
\hline & Місткість ринку & $31 \%$ & & 6,7 & 7,6 & 0,59 & 0,66 \\
\hline \multirow{3}{*}{ Споживча } & Індивідуальність & $35 \%$ & \multirow{3}{*}{$27 \%$} & 7,4 & 6,4 & 0,69 & 0,60 \\
\hline & Цінність & $30 \%$ & & 6,8 & 5,9 & 0,54 & 0,47 \\
\hline & Лідерство & $35 \%$ & & 9,4 & 8,4 & 0,88 & 0,79 \\
\hline \multirow{4}{*}{ Сприйняття } & Імідж & $41 \%$ & \multirow{3}{*}{$23 \%$} & 9,1 & 8,3 & 0,87 & 0,79 \\
\hline & Лояльність & $30 \%$ & & 9,5 & 6,9 & 0,66 & 0,48 \\
\hline & Обізнаність & $30 \%$ & & 9,8 & 7,4 & 0,68 & 0,51 \\
\hline & & & & & & 8,49 & 7,58 \\
\hline
\end{tabular}

Джерело: авторська розробка 
Таблиця 6

Рівні ринкових позицій бренду

\begin{tabular}{|c|c|}
\hline Шкала значень $\mathbf{P}_{\text {brand }}$ & Позиція \\
\hline $\mathrm{P}_{\text {brand }}=0$ & Відсутність позицій \\
\hline $0<\mathrm{P}_{\text {brand }}<2,5$ & Критична \\
\hline $2,5<\mathrm{P}_{\text {brand }}<5,0$ & Нестійка \\
\hline $5,0<\mathrm{P}_{\text {brand }}<7,5$ & Достатня \\
\hline $7,5<\mathrm{P}_{\text {brand }}<10$ & Нормальна \\
\hline $\mathrm{P}_{\text {brand }}=10$ & Абсолютна \\
\hline
\end{tabular}

Джерело: авторська розробка

В цьому разі маємо, що бренд компанії «А» має більшу силу $\mathrm{P}_{\text {brand }}=8,49$, тоді як конкурент має $\mathrm{P}_{\text {brand }}=7,58$. Хоча обидва бренди перебувають на нормальному рівні ринкових позицій.

У подальшому пропонується проводити опитування споживачів за цими параметрами й з огляду на визначену експертами у табл. 4 вагомість кожного параметру оцінювати рівень ринкових позицій своїх брендів за шкалою, наведеною у табл. 6.

За результатами здійснених розрахунків можна оцінити конкурентоспроможність бренду та його позиції порівняно з іншими.

Для цього рекомендується застосовувати циклограму позицій бренду.

Побудуємо циклограму на основі опитування експертів компаній «А» та «Б», а також їх однойменних брендів.

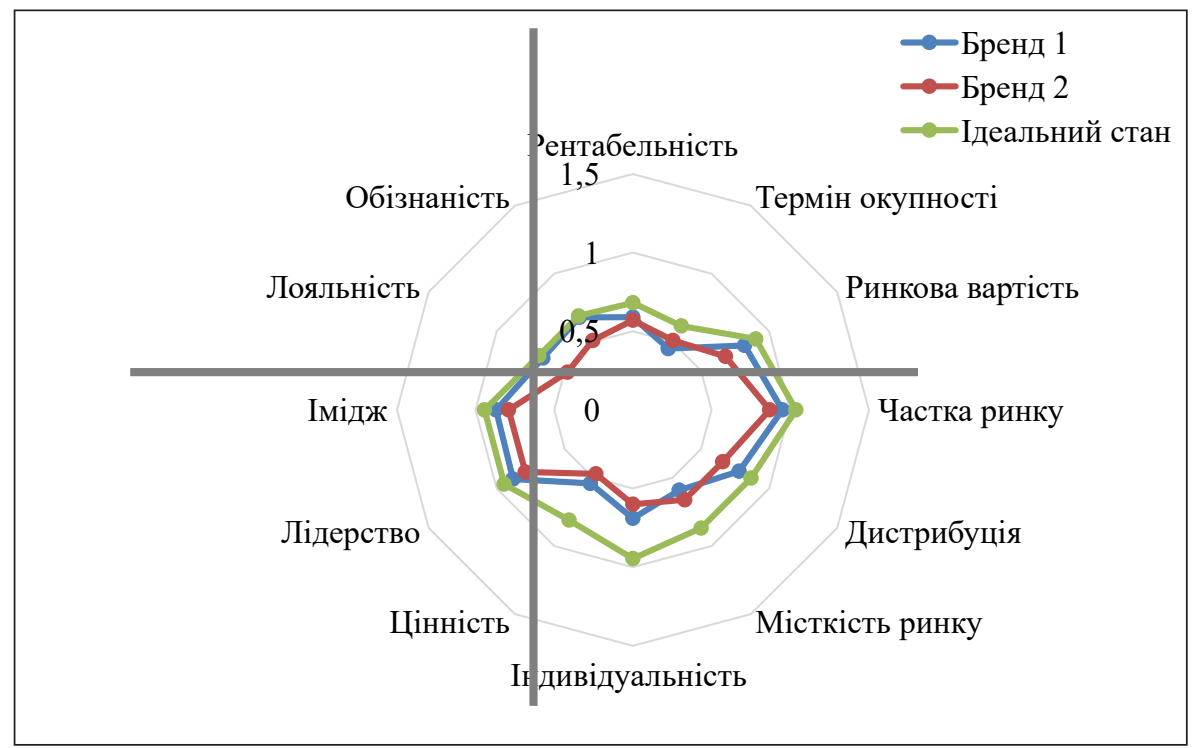

Рис. 2. Циклограма ринкових позииій бренду

Джерело: авторська розробка

За допомогою графічного зображення є можливість оцінити становище серед конкурентів, а також відставання від ідеального стану, зокрема позиції, які необхідно посилити, те, що є більш вагомим. 
Висновки. Отже, проаналізовані та виявлені авторами параметри й фактори оцінювання дають змогу комплексно оцінити конкурентоспроможність та силу бренду 3 чотирьох сфер, а саме фінансової, ринкової, сприйняття та споживацької. За допомогою цієї методики оцінювання компанія має можливість визначити конкурентну позицію свого бренду на ринку, його становище на ринку відносно конкурентів, слабкі та сильні сторони бренду та групи, що потребують особливої уваги.

Загалом питання дослідження бренду є дуже актуальним з огляду на динамічний ринок, безперечно, запропоновані фактори оцінювання бренду можуть бути змінені через декілька років залежно від ситуації на ринку, тому ця тема $є$ невичерпною і буде надалі слугувати основою для подальших досліджень.

\section{Список використаних джерел:}

1. Lehmann D.R., Keller K.L., Farley J.U. The Structure of Survey-Based Brand Metrics. Journal of International Marketing. 2008. Vol. 16. № 4. P. 29-56.

2. Munoz T., Kumar S. Brand Metrics: Gauging and Linking Brands with Business Performance. Journal of Brand Management. 2004. Vol. 11. № 5. P. 381-387.

3. Аакер Д. Создание сильных брендов / пер. с англ. Москва : Издательский дом Гребенщикова, 2003. 425 с.

4. Амблер Т. Практический маркетинг / Пер. с англ. Санкт-Петербург : Питер, 1999. 250 с.

5. Шеррингтон М. Незримые ценности бренда / пер. с англ. Москва : Вершина, 2006. 304 с.

\section{References:}

1. Lehmann D.R., Keller K.L., Farley J.U. (2008) The Structure of Survey-Based Brand Metrics. Journal of International Marketing, vol. 16, no. 4, pp. 29-56.

2. Munoz T., Kumar S. (2004) Brand Metrics: Gauging and Linking Brands with Business Performance. Journal of Brand Management, vol. 11, no. 5, pp. 381-387.

3. Aaker D. (2003) Sozdaniye silnykh brendov [Building strong brands]. Moscow: Izdatel'skij dom Grebenshchykova. (in Russian)

4. Ambler T. (1999) Prakticheskiy marketing [From advertising to zen]. SPB: Piter. (in Russian)

5. Sherrington M. (2006) Nezrimyie tsennosti brenda [Added value]. Moscow: Vershyna. (in Russian) 